E3S Web of Conferences 1, 38004 (2013)

DOI: $10.1051 / \mathrm{e} 3 \operatorname{sconf} / 20130138004$

(C) Owned by the authors, published by EDP Sciences, 2013

\title{
GEMAS: The geochemical mapping of agricultural and grazing land soils of Europe
}

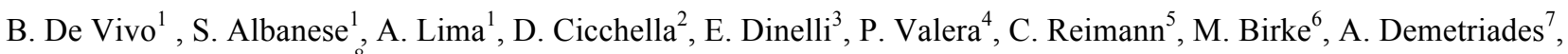 \\ the GEMAS Project Team ${ }^{8}$
}

${ }^{1}$ Università degli Studi di Napoli Federico II, Dipartimento di Scienze della Terra, Via Mezzocannone 8, 80134, Napoli, ITALY, bdevivo@unina.it

${ }^{2}$ Università del Sannio, Dipartimento di Scienze per la Biologia, la Geologia e l'Ambiente, Via dei Mulini, 59/A, 82100, Benevento, ITALY, cidom@unisannio.it

${ }^{3}$ University of Bologna, Department of Earth Science, Piazza di Porta San Donato 1, I-40126 Bologna, ITALY, enrico.dinelli@unibo.it

${ }^{4}$ Università di Cagliari, Dipartimento di Geoingegneria e Tecnologie Ambientali, Piazza D’Armi

09123, Cagliari, ITALY, paolo@paolov.net

${ }^{5}$ Geological Survey of Norway, PO Box 6315 Sluppen, N-7491 Trondheim, NORWAY, clemens.reimann@ngu.no

${ }^{6}$ Federal Institute for Geosciences and Natural Resources (BGR), Stilleweg 2, 30655 Hannover, GERMANY, manfred.birke@bgr.de

${ }^{7}$ Institute of Geology and Mineral Exploration, Entrance C, Olympic Village, Acharnae, GR-13677, Athens, GREECE, ademetriades@igme.gr

${ }^{8}$ M. Andersson, A. Arnoldussen, M.J. Batista, A. Bel-lan, W. De Vos, M. Duris, A. Dusza, O.A. Eggen, M. Eklund, V. Ernstsen, P. Filzmoser, D. Flight, M. Fuchs, U. Fugedi, A. Gilucis, M. Gosar, V. Gregorauskiene, A. Gulan, J. Halamić, E. Haslinger, P. Hayoz, R. Hoffmann, J. Hoogewerff, H. Hrvatovic, S. Husnjak, C.C. Johnson, G. Jordan, L. Kaste, B. Keilert, J. Kivisilla, V. Klos, F. Krone, P. Kwecko, L. Kuti, A. Ladenberger, J. Locutura, D. P.Lucivjansky, D. Mackovych, B.I. Malyuk, R. Maquil, P. McDonnell, R.G. Meuli, N. Miosic, G. Mol, P. Négrel, P. O'Connor, R. T. Ottesen, A. Pasieczna, W. Petersell, S. Pramuka, C. Prazeres, U. Rauch, H. Reitner, I. Salpeteur, N. Samardzic, A. Schedl, A. Scheib, I. Schoeters, P. Sefcik, F. Skopljak, I. Slaninka, A. Šorša, T. Stafilov, E. Sellersjö, V.Trendavilov, V. Verougstraete, D. Vidojević, Z. Zomeni

\begin{abstract}
The GEMAS project started in 2008 with a joint field campaign of almost all geological surveys in Europe in cooperation with some external organizations. 2211 samples of agricultural soil and 2118 samples from land under permanent grass cover were collected from a large part of Europe over a total area of about 5 million sqkm. Analysis of 53 chemical elements were carried out and The initial results indicate that nature, geology and climate are the major driving forces for the mapped distribution of element patterns at the European scale. Once completed, this project will deliver good quality and comparable exposure data of metals in agricultural and grazing land soil.
\end{abstract}

Key words: Heavy metals, GEMAS project, grazing land, agricultural soil

\section{Introduction}

In Europe, the new chemicals regulation REACH (Registration, Evaluation and Authorisation of Chemicals) adopted in December 2006 (EC 2006a, 2009) and the pending EU Soil Framework Directive (Van Camp et al 2004, EC 2006b) have increased the need for knowledge about soil quality at the European scale. In contrast to human-made organic substances, arsenic and many other potentially harmful elements occur naturally in the environment. Thus the natural background variation needs to be established in addition to a methodology to differentiate the industrial impact from the natural geogenic background. A sound documentation of element concentrations and their variation in agricultural and grazing land soil at the continental scale is needed before political actions are taken and such data are also urgently needed at the continental scale in forensic 
chemistry. For example, regional differences can be used to trace the origin of food.

In 2008, the Association of the Geological Surveys of Europe (EuroGeoSurveys) in cooperation with Eurometaux established the GEMAS (GEochemical Mapping of Agricultural Soils) project to gather harmonized geochemical data throughout Europe according to REACH requirements (sampling according to land use and a fixed sample depth - Reimann et al. 2009).

The GEMAS project started in 2008 with a joint field campaign of almost all geological surveys in Europe in cooperation with some external organizations (e.g. Alterrain The Netherlands, several universities and the Norwegian Forest and Landscape Institute).

The data from the GEMAS geochemical mapping survey can be used to answer the question of whether natural or anthropogenic arsenic sources dominate the element distribution at the European scale. The high-quality GEMAS data provide a solid and reliable scientific data base for the recommendation of guideline levels for potentially toxic elements in European agricultural soils.

\section{Materials and Methods}

For the GEMAS project 2211 samples (including field duplicates) of agricultural soil (Ap, Ap-horizon, 0-20cm) and 2118 samples (including field duplicates) from land under permanent grass cover ("grazing land" - Gr, topsoil

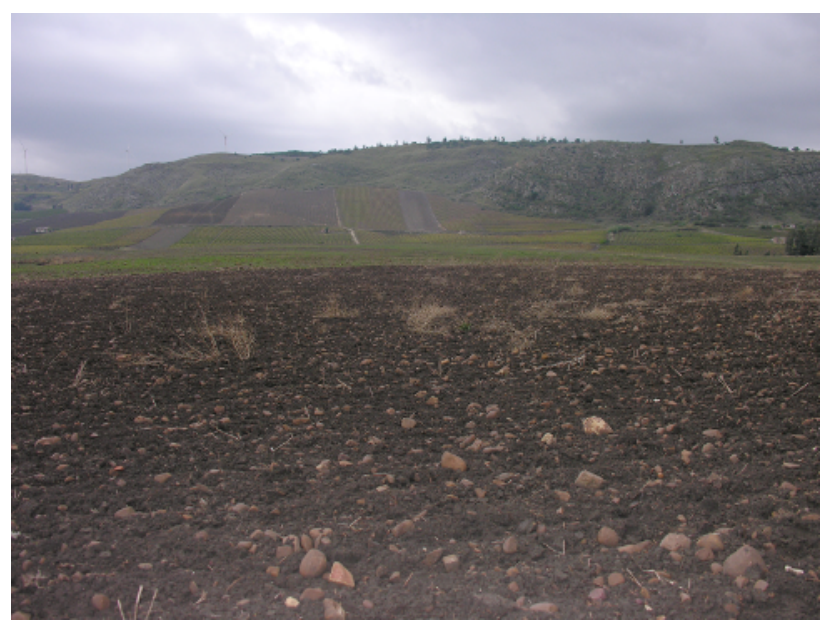

0-10 cm) were collected from a large part of Europe over a total area of about 5 million sqkm (Fig. 1).

Fig. 1. An agricultural soil (Ap) sampling site in Italy (Sample ITA011)

Samples were centrally prepared (air dried, sieved to $<2 \mathrm{~mm}$, homogenised and split into sub-samples) and randomised prior to being sent out to contract laboratories. QC consisted of

- collection of a field duplicate at a rate of 1 in 20 field samples;

- $\quad$ preparation of two large project standards ("Ap" and "Gr") for insertion between the routine project samples;
- preparation of an analytical replicate from each field duplicate

- $\quad$ randomisation of all samples prior to analysis. Analysis of 53 chemical elements (Ag, Al, As, Au, $\mathrm{B}, \mathrm{Ba}, \mathrm{Be}, \mathrm{Bi}, \mathrm{Ca}, \mathrm{Cd}, \mathrm{Ce}, \mathrm{Co}, \mathrm{Cr}, \mathrm{Cs}, \mathrm{Cu}, \mathrm{Fe}, \mathrm{Ga}, \mathrm{Ge}, \mathrm{Hf}$, $\mathrm{Hg}$, In, K, La, Li, Mg, Mn, Mo, Na, Nb, Ni, P, Pb, Pd, Pt, Rb, Re, S, Sb, Sc, Se, Sn, Sr, Ta, Te, Th, Ti, Tl, U, V, W, $\mathrm{Y}, \mathrm{Zn}, \mathrm{Zr}$ ), following an aqua regia extraction on a $15 \mathrm{~g}$ aliquot per sample of both sample materials were performed. All analyses were carried out within twenty days at ACME laboratories in Vancouver, Canada. No serious quality problems, other than a few occasional outliers for a number of elements $(\mathrm{B}, \mathrm{Ca}, \mathrm{Cu}, \mathrm{S}$ and $\mathrm{Sn})$ were detected, and the analytical results were accepted after investigating the reasons for these outliers.

By applying advanced GIS and geostatistical methods, geochemical maps of analyzed elements are now being produced.

\section{Results and Discussion}

The "Geochemical Atlas of Agricultural and Grazing Land Soil of Western Europe" will be published in 2013 and all the geochemical data will be released to the general public.

At the moment, the initial results indicate that nature, geology and climate are the major driving forces for the mapped distribution of element patterns at the European scale, while possible anthropogenic inputs (industry, agriculture, etc.) do not clearly dominate observed elemental distribution (Fig. 2).

\section{Conclusion}

Once completed, this project will deliver good quality and comparable exposure data of metals in agricultural and grazing land soil; in addition, soil properties known to influence the bioavailability and toxicity of metals (and other elements) will be determined in soil at the European scale.

\section{References}

EC, 2006a. Regulation (EC) No 1907/2006 of the European Parliament and of the Council of 18 December 2006 concerning the Registration, Evaluation, Authorisation and Restriction of Chemicals (REACH), establishing a European Chemicals Agency, amending Directive 1999/45/EC and repealing Council Regulation (EEC) No 793/93 and Commission Regulation (EC) No $1488 / 94$ as well as Council Directive 76/769/EEC and Commission Directives 91/155/EEC, 93/67/EEC, 93/105/EC and 2000/21/EC. Official Journal of the European Union, Luxemburg, L 396/1-849 [http://ec.europa.eu/environment/chemicals/reach/re ach_intro.htm].

EC, 2006b. Thematic Strategy for Soil Protection. 

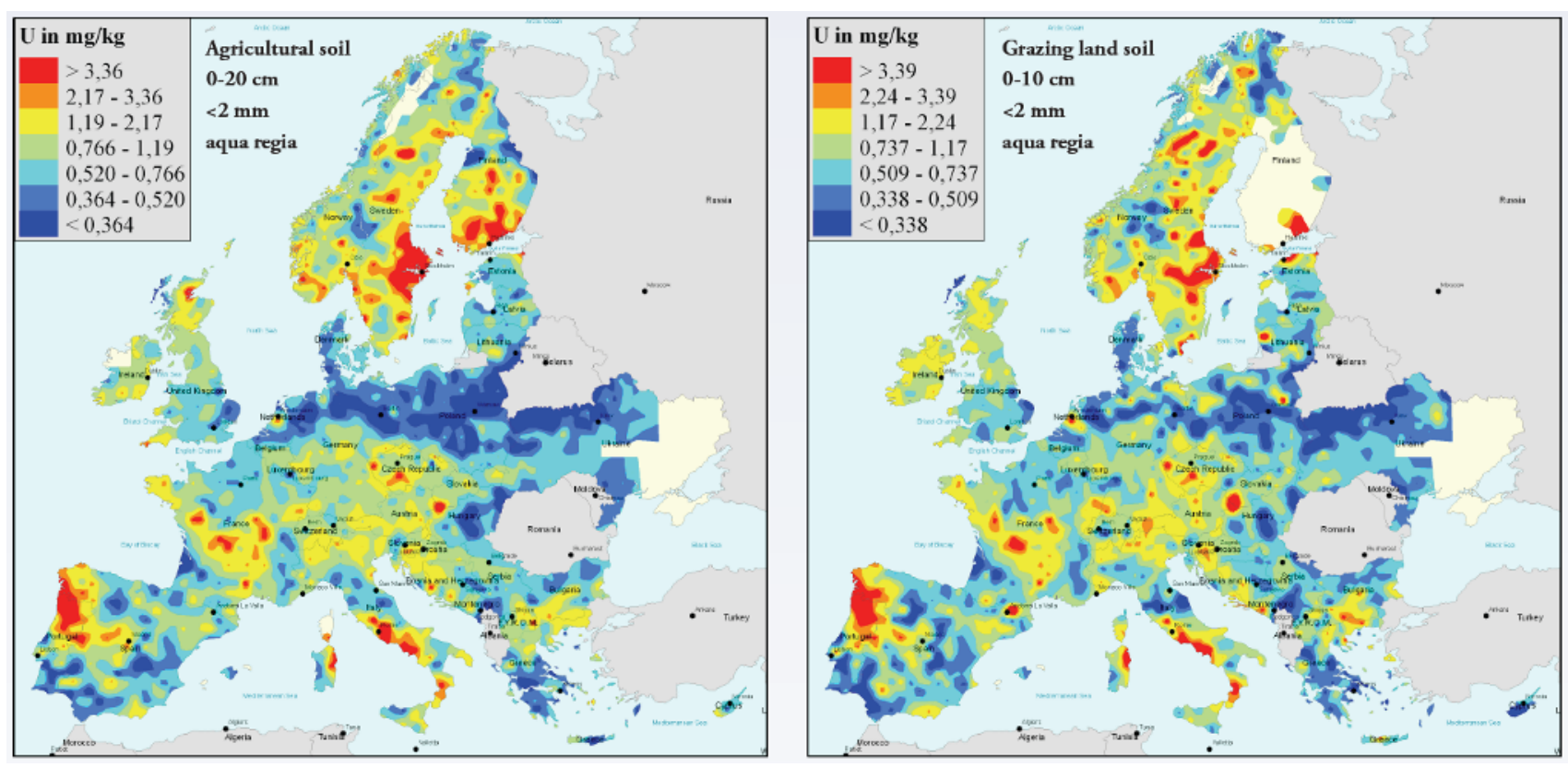

Fig. 2. The preliminary maps of U in Agricultural (Ap) and Grazing land (Gr) soils of Europe.

Communication from the Commission to the Council, the European Parliament, the European Economic and Social Committee and the Committee of the Regions. Commission of the European Communities, Brussels, 22.9.2006, $\operatorname{COM}(2006) 231 \quad$ final, $12 \mathrm{p}$. [http://eur-lex.europa.eu/smartapi/cgi/sga_doc?smar tapi!celexplus!prod!DocNumber\&lg=en\&type_doc $=$ COMfinal\&an_doc $=2006 \&$ nu_doc $=231]$.

EC, 2009. Towards 2020: Making Chemicals Safer - The EU's contribution to the Strategic Approach to International Chemicals Management. Office for Official Publications of the European Communities, Luxemburg, 40p. [http://ec.europa.eu/environment /chemicals/reach/pdf/SAICM_09\%20_en.pdf].
Van-Camp, L., Bujarrabal, B., Gentile, A.R., Jones, R.J.A., Montanarella, L., Olazabal, C., Selvaradjou, S-K., 2004. Reports of the Technical Working Groups established under the Thematic Strategy for Soil Protection, volumes 1 to 6 . [http://eusoils.jrc.ec.europa.eu/ESDB_Archive/euso ils_docs/doc.html\#OtherReports].

Reimann, C., Demetriades, A., Eggen, O.A., Filzmoser, P. \& EuroGeoSurveys Geochemistry group. 2009. The EuroGeoSurveys geochemical mapping of agricultural and grazing land soils project (GEMAS) - Evaluation of quality control results of aqua regia extraction analysis. NGU Report 2009.049. Geological Survey of Norway. Trondheim. $92 \mathrm{p}$. 